\title{
Nitrogen cycling in sediments of the Lagoon of Venice, Italy
}

\author{
Jonas Martin Svensson ${ }^{1, *}$, Giovanni Marco Carrer ${ }^{2}$, Martina Bocci $^{2}$ \\ 'Department of Ecology/Limnology, Ecology Building, University of Lund, 22362 Lund, Sweden \\ ${ }^{2}$ Dipartimento di Processi Chimici dell'ingegneria, Universitá di Padova, Via Marzolo 9, 35 131 Padova, Italy
}

\begin{abstract}
In order to identify the importance of different areas for nitrogen retention in the Lagoon of Venice, ltaly, undisturbed sediment cores of different origin were collected in late April 1998. The cores were transferred to the laboratory and incubated for denitrification activity using the method of 'nitrogen isotope pairing'. The sampled sediments were collected in a freshwater stream (Stn A), an intertidal area (Stn B), in an area characterised by Ulva sp. (Stn C) and in an area vegetated by Zostera sp. (Stn D). Stn D was close to the lagoon outlet (mouth) and highly affected by tidal actions. The ambient concentrations of water column nitrate ranged from 132 to $4.4 \mu \mathrm{M}$. The highest denitrification rate was found in the area with the highest concentration of water nitrate, i.e. at Stns A and B, $292 \pm 75$ and $204 \pm 52 \mu \mathrm{mol} \mathrm{m} \mathrm{m}^{-2} \mathrm{~h}^{-1}$, respectively. Sediment denitrification in the areas closer the lagoon outlet was significantly lower, $16 \pm 2 \mu \mathrm{mol} \mathrm{m} \mathrm{m}^{-2} \mathrm{~h}^{-1}$ at Stn $\mathrm{C}$ and $11 \pm 2 \mu \mathrm{mol} \mathrm{m} \mathrm{m}^{-2} \mathrm{~h}^{-1}$ at Stn D. Oxygen and nitrate consumption, release of ammonium and denitrification in the sediment at $S \operatorname{tn} B$ was correlated to the biomass of benthic infauna. About $30 \%$ of the denitrification in the B sediment was explained by the presence of benthic infauna. More than $50 \%$ of the denitrification in the sediment at Stn $D$ was due to denitrification of nitrate produced by nitrification.
\end{abstract}

KEY WORDS: Denitrification · Sediment $\cdot$ Bioturbation $\cdot$ Lagoon of Venice

\section{INTRODUCTION}

The Lagoon of Venice, Italy, has, since the fourteenth century, changed in surface area and also from being a freshwater environment to a strictly estuarine/marine one, due to intense modification by man-made interactions (Albani et al. 1991, Bendoricchio et al. 1993, 1994). Responsible for these modifications were the anthropogenic impact of river diversion, reclamation of land for agricultural and industrial purposes and also the need of transportation within the lagoon. The anthropogenic impact is also considered to be the main reason for the observed (over the last $50 \mathrm{yr}$ ) increase in discharge of nutrients and pollution to the lagoon water. From agricultural, civil and industrial sources, 6650 tons of nitrogen reach the lagoon water every year (CVN 1998). As nitrogen has also been identified as a factor limiting phytoplankton production in certain coastal marine environments (e.g. Granéli et al.

•E-mail: jonas.svensson@limnol.lu.se
1990), nitrogen seems to be the limiting nutrient for macroalgae growth in the Lagoon of Venice, based on the few available data (Sfriso 1995, Sfriso \& Marcomini 1999). Whether this condition can be presently extended to the major part of the lagoon area and to the whole year has still to be clarified. Although the capacity of the lagoon to purify itself by algal assimilation is considered high (2000 tons of $\mathrm{N} \mathrm{yr}^{-1}$, Sfriso et al. 1988), and that parts of the excess nitrogen are washed out to the sea during tidal action, the remaining nitrogen creates hypertrophic conditions in the inner parts of the lagoon. These areas are identified as those where low flows occur, shallow waters allow the penetration of light, polluted water is discharged from the mainland and sediments have high contents of carbon and nutrients (Bendoricchio et al. 1994). The average annual concentration of total inorganic nitrogen in the inner parts of the lagoon often exceeds $1.5 \mathrm{mg} \mathrm{l}^{-1}$, mainly in the form of nitrate that regularly reaches a high concentration in areas near industrial point sources and effluent river discharge (CVN 1996). 
In the Lagoon of Venice, the circulation of nutrients between water column and sediment, as well as the lagoon life cycles of macroalgae and macrophytes (mainly Ulva sp. and Zostera sp.) have been studied and modelled (cf. Sfriso et al. 1988, 1992a, Bendoricchio et al. 1994, Sfriso \& Marcomini 1994, 1999, Bocci et al. 1997, Coffaro \& Bocci 1997). Much of the variation in water nutrients is related to the fluctuation of macroalgal biomass, particularly at high-standing stock values (Sfriso et al. 1988). However, the main part of the nutrients in the algal biomass is buried in the sediment during its degradation and then released to the water when decomposed.

In the lagoon sediment, the importance of several nutrient-recycling bacterial processes have been identified but they have largely been neglected in the investigations. The main microbial process is considered to be denitrification (Sfriso \& Marcomini 1994, Silvéstri et al. 1995), transferring water nitrate to atmospheric and 'harmless' nitrogen. Generally denitrification is shown to be the most significant process of removing nitrogen in both freshwater wetlands (e.g. Seitzinger 1988, Fleischer et al. 1991, Leonardson 1994) and estuaries (Billen et al. 1985, Seitzinger 1988). However, as reported by Nielsen et al. (1995), the generally short residence time of the water in estuaries, $<14 \mathrm{~d}$, may prevent effectiveness of denitrification due to a lack of physical contact between water and sediment. In the Lagoon of Venice however, no experiments have been carried out in order to assess the field activity of denitrification, and the spatial and temporal distributions of the process are unclear.

This study was performed in order to estimate the fluxes of nitrogen species and the rates and variation of denitrification in undisturbed sediment cores sampled at 4 benthic sites in the Lagoon of Venice from a river outlet near the watershed to one of the lagoon mouths, along a gradient of both nutrients and salinity.

\section{MATERIAL AND METHODS}

Site description and sampling. The Lagoon of Venice (Fig. 1) is a shallow body of water with an average depth of $1 \mathrm{~m}$ and with a total area of $540 \mathrm{~km}^{2}$; it is separated from the Adriatic Sea by narrow sand bars (Flindt et al. 1997). The normal maximal tidal excursion is $1.0 \mathrm{~m}$ (Calvo et al. 1991) and average tidal excursion is $0.6 \mathrm{~m}$. The bottom sediment of the Lagoon of Venice is composed primarily of clayey silts in the zones of tidal flats and sands to silty sands in the main channels and near the entrances of the inlets (Albani et al. 1991).

Sampling (Fig. 1) was performed in late April at 4 stations (Stns A to D) along a transect from the outlet of the Dese River in the lagoon to one of the lagoon mouths (Malamocco). The sampling sites differed in sediment, fauna and vegetation characteristics according to Table 1 . The residence time of the lagoon water did not exceed $10 \mathrm{~d}$ in any of the investigated areas (CVN 1996).

Stn A: The Dese River mainly drains agricultural land and it therefore carries high amounts of nutrients to the lagoon (Bendoricchio et al. 1995). Small stands of Phragmites sp. cover the littoral parts of the strongly canalised river. Sediment cores were collected littorally at a water depth of $0.5 \mathrm{~m}$ some $\mathrm{km}$ upstream from the river outlet to the lagoon. This sediment, with a high content of water and organic material, was comprised of clay, silt and smaller and larger parts of detritus, mainly of Phragmites sp. origin. A low biomass of chironomids and polychaetes was observed in the sediment. Occasionally, saline water intrudes several $\mathrm{km}$ upstream from the Dese River, giving rise to fluctuating salinity in the water column. At the time of the sampling however, $0 \%$ of salinity was observed. The Dese River discharges high amounts of nutrients to the lagoon annually (Bendoricchio et al. 1995), but this type of environment (river outlets) does not constitute any significant surface area of the lagoon.

Stn $B$ : The river water eventually discharges into an area of tidal flats. This environment is highly influenced by the tidal actions and the daily water depth ranges between 0 and $1 \mathrm{~m}$. A high abundance of poly-

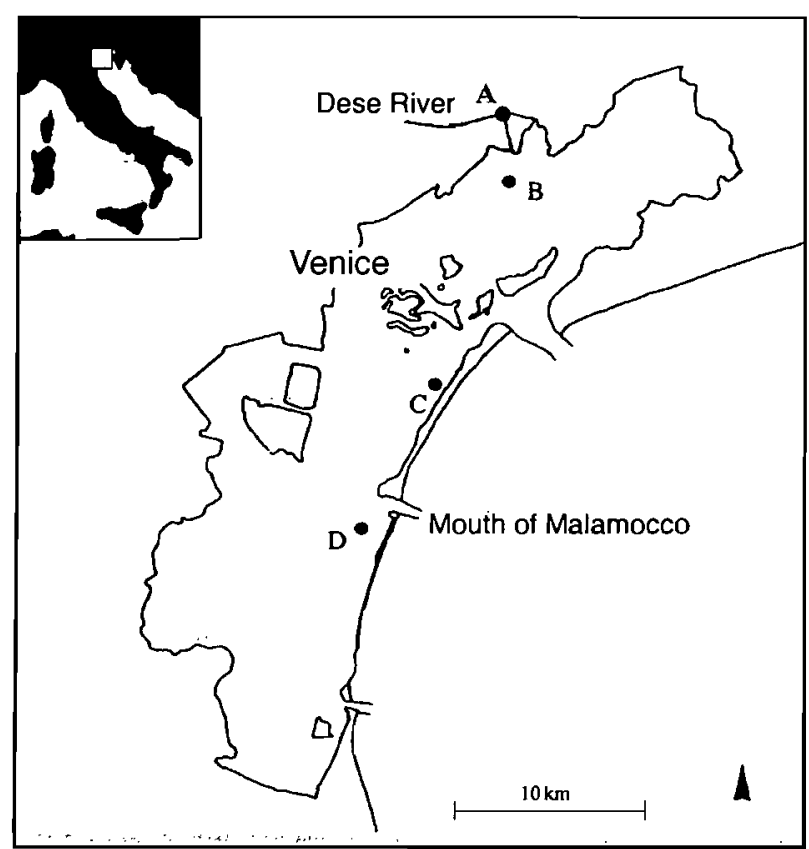

Fig. 1. Map of the Lagoon of Venice, Italy. Sampling Stns A to $\mathrm{D}$ are indicated in the lagoon 
Table 1. Sediment characteristic at the respective Stns A to D. Dominating groups of vegetation and benthic infauna are indicated in the table as well as water residence time at each station and the estimated area of sediment which could be representative for each station. Chir.: chironomids

\begin{tabular}{|c|c|c|c|c|c|c|c|c|}
\hline $\begin{array}{l}\text { Sampling } \\
\text { station }\end{array}$ & $g$ Composition & $\begin{array}{l}\text { - Sediment } \\
\text { Porosity } \\
(\%)\end{array}$ & $\begin{array}{c}\text { Org. Ca } \\
(\%)\end{array}$ & $\overline{\substack{\mathrm{C} / \mathrm{N} \text { ratio } \\
(\mathrm{mol})}}$ & $\begin{array}{c}\text { Water } \\
\text { residence } \\
\text { time (d) }\end{array}$ & $\begin{array}{l}\text { Macrobenthos } \\
\text { (dom. groups) }\end{array}$ & $\begin{array}{c}\text { Vegetation } \\
\text { (dom. groups) }\end{array}$ & $\begin{array}{c}\text { Lagoon } \\
\text { coverage } \\
(\%)\end{array}$ \\
\hline A & Clay/silt/detritus & $78 \pm 2$ & $14 \pm 1$ & $14 \pm 2$ & $0-5$ & Chir./polychaetes & Phragmites sp. & $<1$ \\
\hline B & Clay/silt/fine sand & $43 \pm 3$ & $8 \pm 1$ & $38 \pm 2$ & $5-10$ & Polychaetes/amphipods & - & 10 to 20 \\
\hline C & Clay/silt & $54 \pm 6$ & $12 \pm 1$ & $28 \pm 4$ & $0-5$ & - & Ulva sp. & 20 to 30 \\
\hline $\mathrm{D}$ & Silt/fine sand/sand & $35 \pm 7$ & $7 \pm 1$ & $52 \pm 21$ & $0-5$ & - & Zostera sp. & ca $30^{b}$ \\
\hline \multicolumn{9}{|c|}{$\begin{array}{l}\text { a Top } 3 \mathrm{~cm} \text { of the sediment } \\
{ }^{\mathrm{b}} \text { This value does not include areas not covered by Zostera sp. but includes those with similar sediment compositions and } \\
\text { environment conditions }\end{array}$} \\
\hline
\end{tabular}

chaetes and amphipods were observed at this site, but no vegetation. Samples were taken at high tide at a depth of $0.5 \mathrm{~m}$. Being exposed to both the river water and the outer saline lagoon water, salinity and nutrient concentrations in the water column vary considerably with the tidal actions. At the sampling occasion, salinity was $17 \%$. This type of environment (intertidal flats) represents at maximum of about 10 to $20 \%$ of the total lagoon sediment surface area.

Stn C: Between the Island of Sacca Sessola and Lido in the central part of the lagoon there is an area densely covered with submersed un-rooted Ulva sp. that moves around in response to wind and wave action. About $30 \%$ of the total lagoon area is characterised by shallow waters, where Ulva sp. seasonally appears, that sometimes result in bottom water anoxia (Izzo et al. 1995). Since the overall water movements in this part of the lagoon are lower compared to the fluctuations found in other areas, the sediment comprises up to $80 \%$ fine material (Sfriso \& Marcomini 1994). Sampling of sediment was made at a depth of $1 \mathrm{~m}$ within a small area where no macroalgae were present at that time.

Stn $D$ : This benthic environment, being the most representative of the lagoon area, is spatially vegetated by populations of rooted stands of Zostera sp. that cover the sediment to various extents. Small individuals of un-rooted Ulva sp. also occur at this site. Albani et al. (1991) characterised this area as a marine subbiotope. The lagoon water in this part is subjected to good exchange with the Adriatic Sea waters through the Malamocco inlet. Sampling was carried out between 0.5 and $1 \mathrm{~m}$ in a shallow area just south of the Malamocco port entrance. The sediment sampled at this site had a low density of infaunal macrobenthos and was only populated by small stands of vegetation. Inevitably however, the vegetation trapped in the sediment cores, to various degrees, was damaged by the sampling.
Sediment characteristics. Sediment characteristics at the respective sites were determined by standard methods of drying and burning. Analysing the $\mathrm{C} / \mathrm{N}$ ratio also compared the top $3 \mathrm{~cm}$ of sediments by the use of a CHN elemental analyser (Fisons Instrument model NA 1500). In Table 1, the average porosity and the organic content are summarised as well as ratios of sediment total carbon and total nitrogen of the top $3 \mathrm{~cm}$ from the 4 sampling stations.

Sediment preparation. Undisturbed sediment cores (16 to 18), were collected in Plexiglas cylinders $(\varnothing=$ $44 \mathrm{~mm}$ ) from a boat by a modified Kajak core sampler at the 5 mentioned stations in the Lagoon of Venice during late April 1998. The sediment cores were transported as quickly and gently as possible by boat and car to the laboratory. From the original 16 to 18 sediment cores, a set of 12 cores was selected. Each core cylinder was equipped with a rotating magnetic stirrer connected to the cylinder wall 10 to $12 \mathrm{~cm}$ above the sediment surface. The open cylinders were then moved to incubation chambers and placed around rotating central magnets and incubated under filtered (25 $\mu \mathrm{m}$ ) water collected at the respective station. The incubation water was air bubbled and the sediment cores were allowed to stabilise at room temperature $\left(18\right.$ to $\left.19^{\circ} \mathrm{C}\right)$ in darkness. Due to the experimental conditions we did not manage to keep the precise in situ water temperature, which ranged between 14 and $16^{\circ} \mathrm{C}$, at the sampling station. The 4 localities were sampled during a sampling period of $2.5 \mathrm{wk}$.

Sediment oxygen consumption. Oxygen measurements were taken during this incubation period to ensure that the magnetic stirring was sufficient to avoid vertical oxygen gradients in the water column and that the systems were in a steady state. In addition to determining the maximum incubation period needed to avoid a decrease of dissolved $\mathrm{O}_{2}$, more than 20 to $30 \%$ of air saturation when later performing the incubations for denitrification was required. 
After ca $24 \mathrm{~h}$, to stabilise the sediment-water system, oxygen consumption was measured in the cores. By use of a syringe, $60 \mathrm{ml}$ of water was withdrawn from each replicate ca 3 to $4 \mathrm{~cm}$ above the sediment surface and transferred to $25 \mathrm{ml}$ Winkler vials, representing the initial oxygen values. After gentle replacement of the withdrawn volume with aerated circulating site water, all cores were immediately capped, and incubated for 5 to $6 \mathrm{~h}$ in darkness under magnetic stirring. After the incubation period, another $60 \mathrm{ml}$ was withdrawn from the same depth as the initial sample, and transferred to $25 \mathrm{ml}$ vials. This final water was withdrawn through a tube mounted in the cap without more than slightly opening the cylinders. After the final sampling for oxygen, which was taken without disturbing the sediment surface, the withdrawn water was replaced and each core was re-incubated. Water samples of nitrogen species for ammonium and nitrate uptake/release (GF/C filtered) were taken at the same occasion as the sampling for oxygen.

Denitrification. After measuring the sediment oxygen consumption, all cores were incubated without stoppers for another day under the filtered station water in the dark at room temperature, during which time they were subjected to continuous magnetic stirring. This was done to allow for stabilisation and equilibrium of the sediment-water processes.

A gradient of nitrate was thereafter established by addition of $\mathrm{K}^{15} \mathrm{NO}_{3}$ to a set of 3 cores in a total of 4 concentrations of nitrate. Additions of $\mathrm{K}^{15} \mathrm{NO}_{3}(99 \%)$ were made to give final labelling from 5 to $75 \%$. By misjudgement of the natural nitrate concentration at the station waters some labelling went below $5 \%$. These measurements have, however, been excluded from further data analysis. The ambient concentrations of nitrate at the sampling sites are shown in Fig. 2. After addition of $\mathrm{K}^{15} \mathrm{NO}_{3}$, the water inside the cores was left for ca $30 \mathrm{~min}$, to allow for homogeneous mixture of the ambient concentration of ${ }^{14} \mathrm{NO}_{3}$ and ${ }^{15} \mathrm{NO}_{3}$ and to allow for the establishment of a stable ${ }^{15} \mathrm{NO}_{3}$ gradient in the sediment surface layer during incubation. Samples for determination of the composition of ${ }^{14 / 15} \mathrm{~N}$-nitrate were then taken, after which they were capped and incubated in darkness for 1.5 to $3 \mathrm{~h}$. The incubation period was set to ensure a maximum oxygen depletion of 20 to $30 \%$. At the end of the incubation the caps were removed and water was withdrawn $(25 \mathrm{ml})$ for later analysis of nitrogen species. Water and the top 5 to $8 \mathrm{~cm}$ of sediment were then gently mixed to slurry with $30 \mathrm{~cm}$ long, stainless steel forceps. Samples of the slurry were transferred to and stored in $12 \mathrm{ml}$ gas-tight glass containers containing $2 \% \mathrm{ZnCl}_{2}$ (50\% saturation) to stop further microbial activity. All containers were stored for about $1 \mathrm{mo}$ at $4^{\circ} \mathrm{C}$ until analysis. Directly after the denitrification sampling, the remaining sedi-

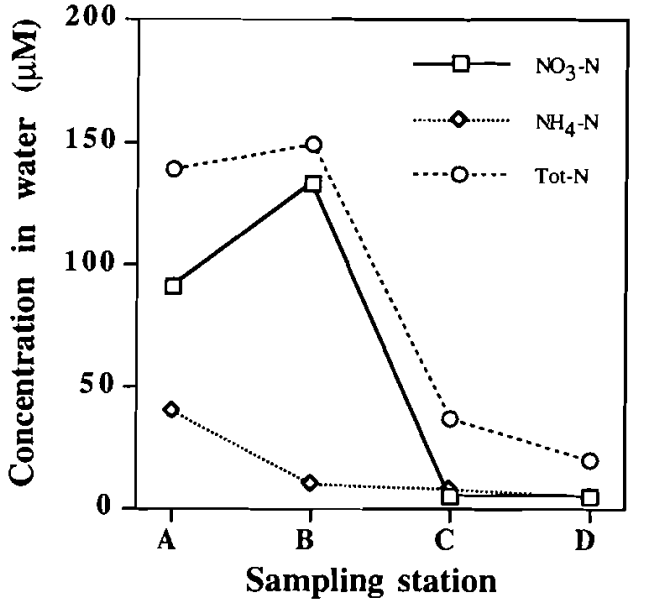

Fig. 2. Concentrations of ambient nitrogen species measured in the water column at the respective station of sampling

ment slurry was sieved, and the number and the total dry weight $\left(105^{\circ} \mathrm{C}\right)$ of the benthic infauna in each core were determined.

Analysis. Dissolved oxygen concentrations were derived from Winkler titration. Ammonium and nitrate+nitrite were determined according to Chaney \& Marbach (1962) and Wood et al. (1967), respectively, on a Technicon Auto Analyser II. Total nitrogen was determined by use of a Total Nitrogen analyser (ANTEK 9000 Series) employing the high temperature combustion technique. The $12 \mathrm{ml}$ water samples for denitrification measurements were analysed according to the Nitrogen Isotope Pairing technique (Nielsen 1992). Three $\mathrm{ml}$ of the sample water was replaced by helium. After vigorous shaking, $30 \mu \mathrm{l}$ of the gas phase was injected in a gas chromatograph in line with an isotope-ratio mass spectrometer (Europe Scientific, Crewe, UK) for ${ }^{15} \mathrm{~N}$-labelled dinitrogen pairs $\left({ }^{14} \mathrm{~N}^{15} \mathrm{~N}\right.$ and ${ }^{15} \mathrm{~N}^{15} \mathrm{~N}$ ) formed by denitrification (Hauck et al. 1958, Nielsen 1992). The ${ }^{15} \mathrm{NO}_{3}$ enrichment in the water phase of each core was determined by gas chromatograph-mass spectrometer (GC-MS) analysis after biological reduction to dinitrogen (Risgaard-Petersen et al. 1993). The rates of denitrification per square meter were estimated by using the nitrogen-isotope pairing technique (Nielsen 1992). Denitrification was calculated as the sum of denitrification of nitrate originating from the water phase and denitrification of nitrate coming from nitrification.

Calculations. Net fluxes $(F)$ of oxygen, ammonium and nitrate+nitrite over the sediment surface were calculated by the general flux equation:

$$
F=\left[\left(C_{\mathrm{e}}-C_{\mathrm{i}}\right) \times(V /(A \times t)]\right.
$$

where $C_{\mathrm{e}}$ and $C_{\mathrm{i}}$ are the final and initial concentration, respectively, $V$ is the volume of water in the cores, $A$ is the sediment surface area and $t$ is the incubation time. 
The rates of denitrification per square meter were estimated by using the nitrogen-isotope pairing technique (Nielsen 1992). The production rates of single and double-labelled $\mathrm{N}_{2}$ were calculated from the amounts of ${ }^{15} \mathrm{~N}_{2}$ that accumulated in the cores during the incubation (Pind et al. 1997). These are used to calculate $d_{15}$ and $d_{14}$, which are the rates of denitrification of ${ }^{15} \mathrm{NO}_{3}$ and ${ }^{14} \mathrm{NO}_{3}$, respectively (Nielsen 1992).

$$
\begin{gathered}
d_{15}=\left({ }^{14} \mathrm{~N}^{15} \mathrm{~N}\right)+2\left({ }^{15} \mathrm{~N}^{15} \mathrm{~N}\right) \\
d_{14}=\left[d_{15}\left({ }^{14} \mathrm{~N}^{15} \mathrm{~N}\right)\right] / 2\left({ }^{15} \mathrm{~N}^{15} \mathrm{~N}\right)
\end{gathered}
$$

In situ denitrification ( $d^{14}{ }_{w}$ ) of the ambient concentration of ${ }^{14} \mathrm{NO}_{3}$ in the water:

$$
d^{14}{ }_{w}=d_{15} \times f^{w}{ }_{14} / f^{w}{ }_{15}
$$

where $f^{\mathrm{w}}{ }_{14}$ and $f^{\mathrm{w}}{ }_{15}$ are the frequencies of ${ }^{14} \mathrm{~N}$ and ${ }^{15} \mathrm{~N}$ of the $\mathrm{NO}_{3}$ in the water column, respectively. The rate of denitrification of the nitrate produced by nitrification (coupled nitrification-denitrification, $d_{n}$ ) was calculated as the following difference (Nielsen 1992):

$$
d_{\mathrm{n}}=d_{14}-d^{14} w
$$

The sum of $d^{14}{ }_{w}$ and $d_{n}$ represents the total denitrification as measured in the core.

Statistics. The data material has been tested by running factorial analyses of variance (ANOVAs) and simple linear regressions by use of SYSTAT for Macintosh 5.2.1. The residuals were examined for normality by plotting and by use of the Kolmogorov-Smirnov test of normality (Zar 1974). If normality could not be verified the data were transformed logarithmically before the test.

\section{RESULTS}

\section{Sediments and benthic fauna}

The sediment characteristics from the sampled stations in the lagoon are summarised in Table 1. All sediments were found to contain high amounts of carbon as reflected in high organic content and $\mathrm{C} / \mathrm{N}$ ratios. The lowest amounts of organic matter were found at Stns $B$ and $D$. These stations also had the highest ratios of $\mathrm{C} / \mathrm{N}$.

The benthic fauna, comprising mainly polychaetes, tube-dwelling amphipods Corophium sp. and chironomid larvae, was expressed as total grams of biomass in dry weight $\mathrm{m}^{-2}$ at each station ( $\mathrm{g}$ dry weight $\mathrm{m}^{-2}$ ). The sediment at Stn B was the environment with the highest abundance of benthos (polychaetes and Corophium $\mathrm{sp}$ ). At this station the average biomass was $5.33 \pm 6.5 \mathrm{~g}$ dry weight $\mathrm{m}^{-2}$ with a range up to $20 \mathrm{~g}$ dry weight $\mathrm{m}^{-2}$ in 1 separate core. At Stn A, average biomass was 1.03 $\pm 3.0 \mathrm{~g}$ dry weight $\mathrm{m}^{-2}$. No benthic animals were found at Stns $C$ and D.

\section{Water column nutrient concentrations}

During the sampling period in late April, representing mid-spring conditions in the Lagoon of Venice, a strong decreasing gradient of total nitrogen was detected from Stns A to D (Fig. 2). The highest concentrations of ammonium and nitrate in the lagoon water were measured at the freshwater influent at Stn A (39.6 and $90.9 \mu \mathrm{M}$, respectively) and in the water overlying the intertidal sediment at Stn B (9.7 and $132 \mu \mathrm{M}$, respectively). The concentrations of ammonium and nitrate markedly decreased further along the estuary towards the outlet of the lagoon, and thus, the lowest values of these components were measured in the water overlying Stn $D$ near the outlet $(5.0$ and $4.4 \mu \mathrm{M}$, respectively). Total nitrogen $(<25 \mu \mathrm{m})$ comprised the largest part of nitrate (+nitrite) in the inner parts of the lagoon (Fig. 2). Ammonium did not exceed $30 \%$ of total nitrogen in any station. The values for nitrogen concentrations in the present study reflect what normally is registered in the lagoon during this season.

\section{Oxygen consumption}

The highest rates of oxygen consumption per $\mathrm{m}^{2}$ were observed in the sediments of Stns A and B, $2.4 \pm$ 0.8 and $2.2 \pm 0.6 \mathrm{mmol} \mathrm{m}^{-2} \mathrm{~h}^{-1}$, respectively. Oxygen consumption rates in the Stn B sediment were correlated to benthic biomass (simple regression, $F=13.4$, $r^{2}=0.57, p<0.05, n=12$ ). Despite the high content of organic material within the Stn $C$ sediment, the oxygen uptake at this station, $0.71 \pm 0.6 \mathrm{mmol} \mathrm{m}^{-2} \mathrm{~h}^{-1}$, was only moderate compared to what was measured in the sediment at Stn $B$. The lowest uptake, $0.0 \pm 0.8 \mathrm{mmol}$ $\mathrm{m}^{-2} \mathrm{~h}^{-1}$, was found at Stn D near the outlet of the Adriatic Sea, where no significant consumption of oxygen could be detected during the incubation period of almost $6 \mathrm{~h}$. It should be noted that many cores sampled at Stn D contained individuals of Zostera sp. and smaller parts of Ulva sp., which despite dark incubations, might have produced oxygen or contained excess oxygen produced earlier.

\section{Ammonium fluxes}

The ammonium consumption (Fig. 3) at all stations was negative, i.e. there was a net release of ammonium from all the investigated sediment to the overlying 
water column. The efflux of ammonium was closely related to the sediment organic content (not significant though) where the lowest efflux was detected at Stn D. A general correlation was also observed between ammonium efflux and the sediment oxygen consumption including each core from all stations (simple regression, $F=24.7, \mathrm{r}^{2}=0.30, \mathrm{p}<0.001$, $\mathrm{n}=60$ ). However, variation was high and a significant difference was only detected between Stns A and D ( $p<0.01,2$-way ANOVA). Sediment ammonium consumption at $\mathrm{Stn} B$, as also observed in the case of oxygen consumption, strongly correlated with the benthic biomass $(F=$ $235, \mathrm{r}^{2}=0.96, \mathrm{p}<0.001, \mathrm{n}=12$ ).

\section{Nitrate fluxes}

The sediment nitrate consumption showed a strong decreasing gradient from Stns A to D (Fig. 3). Sediment nitrate consumption at Stns A and B was significantly higher than what was measured in the sediments at Stns $C$ and $D(p<$ 0.05 , ANOVA). The highest nitrate consumption rates were observed at Stn $B$, where data correlated significantly with the benthic biomass $\left(F=11.4, \mathrm{r}^{2}=0.53\right.$, $\mathrm{p}<0.001, \mathrm{n}=12$ ).

\section{Denitrification and coupled nitrification-denitrification}

Denitrification rates were recalculated to ambient nitrate levels as measured at the respective sampling station (Fig. 2). This was done by use of the regression equations determined from the relationship between nitrate and denitrification at the respective station, and by use of the ${ }^{15} \mathrm{~N}$-atom\% in the initial incubation water. The highest rates of denitrification (Fig. 4) of water nitrate $\left(d^{14}{ }_{w}\right)$ as well as denitrification of nitrate produced from nitrification $\left(d_{n}\right)$ were estimated in the sediment at Stn A, $213 \pm 69$ and $79 \pm 46 \mu \mathrm{mol} \mathrm{m}^{-2} \mathrm{~h}^{-1}$, respectively. High rates were also measured at $S \operatorname{tn} B$, where rates of $d^{14}{ }_{w}$ were found to significantly correlate with the benthic biomass (simple regression, $F=$ 10.6, $\mathrm{r}^{2}=0.52, \mathrm{p}<0.01, \mathrm{n}=12$ ). Denitrification rates in Fig. 4 for $S \operatorname{tn} B$ are recalculated to the average biomass of invertebrates found at this station, i.e. $5.3 \mathrm{~g}$ dry weight $\mathrm{m}^{-2}$. Any correlation between benthic biomass and $d_{\mathrm{n}}$ was not found at $\operatorname{Stn} \mathrm{B}$. Lowest activity was recorded in the sediment at the Stn $D$, where $d_{n}$ made up more than $50 \%$ of the total denitrification. At Stns C and D (cf. Fig. 5), denitrification of water column nitrate $\left(d_{15},{ }^{14} \mathrm{NO}_{3}+{ }^{15} \mathrm{NO}_{3}\right)$ was positively correlated to the concentration of nitrate in the water. This was however not observed at Stns A and B. This was explained by the too narrow range of the ${ }^{15} \mathrm{~N}$-nitrate gradient, which was added to these cores due to the misjudgement of the natural water nitrate concentration at these stations. Coupled nitrification-denitrification $\left(d_{14}\right)$ was independent of nitrate concentration in the water column (cf. Fig. 5). It was however not possible to estimate sediment $d_{\mathrm{n}}$ at Stns $\mathrm{A}$ and $\mathrm{B}$ at the 2 lowest concentrations of ${ }^{15} \mathrm{NO}_{3}$ additions. This is likely because the labelling of ${ }^{15} \mathrm{NO}_{3}$ relative to ${ }^{14} \mathrm{NO}_{3}$ was too low $(<5 \%)$

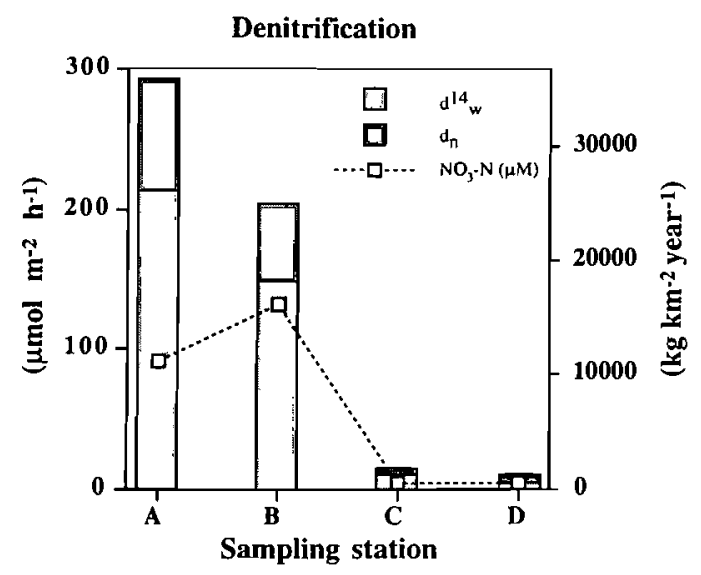

Fig. 4. In situ denitrification ( $\left(d^{14}{ }_{w}\right)$ of water column nitrate and nitrate produced from nitrification $\left(d_{n}\right)$ at the respective - station in relation to ambient nitrate concentration in the water column. Standard deviations are presented in the text 
to give a proper signal on the GC-MS as mentioned above. Although $d^{14}{ }_{w}$ was assumed not to have been affected by the low labelling, average $d^{14}{ }_{w}$ and $d_{n}$ from these stations was estimated from the treatments with labelling over $5 \%$.

\section{DISCUSSION}

\section{Nitrogen-isotope pairing method}

In this study we used the nitrogen-isotope pairing method (Nielsen 1992), which is a further development of the method of analysing the mixture of ${ }^{15} \mathrm{NO}_{3}$ and ${ }^{14} \mathrm{NO}_{3}$ in studies of soil denitrification, introduced by Hauck et al. (1958). By adding ${ }^{15} \mathrm{NO}_{3}$ to the overlying bottom water it is possible to distinguish between denitrification of nitrate diffusing from the water column and denitrification of nitrate produced by the in situ nitrification process, i.e. coupled nitrification-denitrification $\left(d_{n}\right)$.

Certain assumptions must however be fulfilled for the correct application of the method (Nielsen 1992, Rysgaard et al. 1995), which, if not met, will lead to an underestimation of the denitrification rates. The first assumption is that the introduced ${ }^{15} \mathrm{NO}_{3}$ must not interfere with denitrification based on in situ $\mathrm{NO}_{3}$, which is met by the presence of a first-order kinetic relationship between denitrification based on water phase $\mathrm{NO}_{3}$ and the $\mathrm{NO}_{3}$ concentration in the overlying water. The linear correlation found between these parameters at Stns C and D (Fig. 5) confirmed this. At Stns A and B however, we failed to establish this correlation, most likely since the additions of the nitrate gradient were too small in relation to the ambient nitrate concentration $\left({ }^{15} \mathrm{~N}\right.$ labelling was only from 2 up to $\left.20 \%\right)$. Despite this, since the method has been successfully used with sediments similar to the ones sampled at Stns A (Pind et al. 1998) and B (Pelegrí et al. 1994), we assume that the major requirements are also met here. However, it should be stressed that the denitrification rates achieved at Stns A and B may be underestimated because of the above-mentioned reason. A second constraint of the method is that uniform mixing between the added ${ }^{15} \mathrm{NO}_{3}$ and the naturally occurring ${ }^{14} \mathrm{NO}_{3}$ must exist. This can be tested by proving that coupled nitrification-denitrification $\left(d_{14}\right)$ is independent of the nitrate concentration in the water phase. This was generally shown at the stations as exemplified in Fig. 5.

\section{Denitrification and fluxes of nitrogen}

Nitrate in the water column of the Lagoon of Venice controls to a large extent the activity of denitrification.

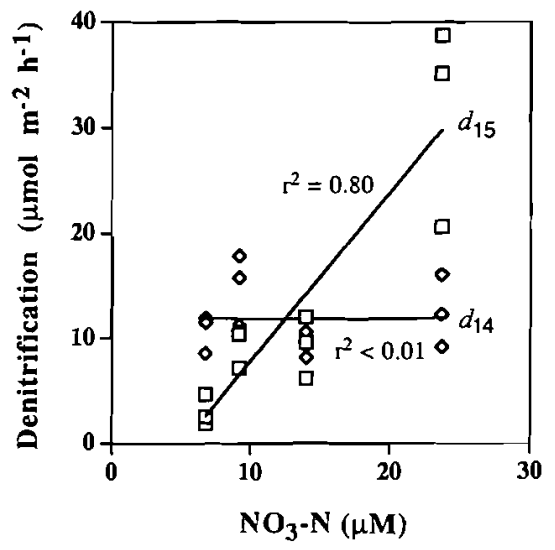

Fig. 5. Denitrification of water column nitrate $\left(d_{15}\right.$, i.e. denitrification of ${ }^{14} \mathrm{NO}_{3}+{ }^{15} \mathrm{NO}_{3}$ ) and of nitrate produced from nitrification $\left(d_{14}\right)$ at $S t n D$ in relation to nitrate concentration in the water. To meet the assumptions underlying the nitrogen isotope pairing method, this experimental set-up was used to verify the linear relationship at each station (see text), i.e. showing 1st order kinetics between water nitrate concentration and $d_{15}$, and that ${ }^{14} \mathrm{NO}_{3}$ and ${ }^{15} \mathrm{NO}_{3}$ are homogeneously distributed

An integrated regression between $d^{14}{ }_{\mathrm{w}}$ in the sediment and nitrate concentration in the water column at all 4 sampling stations resulted in an $\mathrm{r}^{2}$ value of 0.75 . Nielsen et al. (1995) reported $\mathrm{r}^{2}=0.96$ between ${d^{14}}_{\mathrm{w}}$ and nitrate concentration from Norsminde Fjord, Denmark. We also found, as expected, the highest total denitrification $\left(d^{14}{ }_{\mathrm{w}}+d_{\mathrm{n}}\right)$ in the inner parts of the lagoon (Stns A and B), 292 and $204 \mu \mathrm{mol} \mathrm{m} \mathrm{m}^{-2} \mathrm{~h}^{-1}$, where the highest nitrate concentrations were also found. In the Dese River sediment (Stn A), the estimated rate of denitrification is well in range with another Danish study from a lowland stream (Pind et al. 1998). Pind et al. (1998) reported activities of between 0 and $750 \mu \mathrm{mol} \mathrm{m}^{-2} \mathrm{~h}^{-1}$ on an annual basis, with an average of $200 \mu \mathrm{mol} \mathrm{m}^{-2} \mathrm{~h}^{-1}$. The high rates of denitrification shown in the stream sediment may not only be a consequence of the high substrate availability, but also an effect of facilitated diffusive transport of nitrate due to the water currents in streams (Cooke \& White 1987, Pind et al. 1998).

The coupled nitrification-denitrification $\left(d_{\mathrm{n}}\right)$ made up a significant part of total denitrification $\left(d^{14}{ }_{w}+d_{n}\right)$. The highest fraction of denitrification supported by nitrate produced from nitrification $(55 \%)$ was observed at Stn D. The Stn D sediment of the outer sub-marine area contained the lowest amount of organic carbon and had also, somewhat surprisingly, insignificant oxygen consumption over $6 \mathrm{~h}$ incubation, indicating deep oxygen penetration. A longer incubation period would have likely been more adequate to detect the oxygen consumption at this station. Nitrification in this area 
may additionally be enhanced by the presence of Zostera sp. plants, which can contribute to enhanced activity by root-release of $\mathrm{O}_{2}$ to subsurface sediment (Caffrey \& Kemp 1990). On the other hand, deep oxygen penetration increases the distance for nitrate to diffuse to anaerobic sites in the sediment, and thereby in some sense prevents denitrification of water column nitrate. Higher denitrification activity, however, has been estimated in various seagrass communities and freshwater beds of macrophytes relative to adjacent unvegetated areas. This enhancement may be attributed to plant root excretion of DOC or to increased nitrate production by nitrification as stimulated by increased $\mathrm{O}_{2}$ availability (Caffrey \& Kemp 1990, Christensen \& Sørensen 1986). An indication that root excretion of dissolved organic substances may be an important contributor to bacterial activity in the sediment at $\operatorname{Stn} \mathrm{D}$, is the observation of high total nitrogen release from that sediment to the water column, possibly attributed to DON. The effect of DON on denitrification is, however, unclear and was not investigated in this study.

As a result of higher nitrate concentration in the water column, total denitrification in the sediment at Stn $C\left(15.5 \mu \mathrm{mol} \mathrm{m}{ }^{-2} \mathrm{~h}^{-1}\right)$ was higher than at Stn $\mathrm{D}$

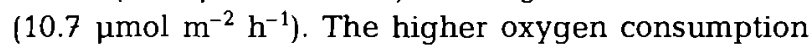
rates at $\mathrm{Stn} C$ indicate more shallow oxygen penetration, and thereby a shorter diffusion distance for nitrate, which is also supported by the lower contribution of $d_{\mathrm{n}}$ to total denitrification $(<30 \%)$. Although pollution discharge is under control today, the sediment of Stn C represents a benthic area that is considered to be one of the most polluted parts of the Lagoon of Venice (Cossu et al. 1983, Sfriso et al. 1992a). Additionally, to improve waterway access to the industrial districts, deep canals have been constructed which have, in large areas, strongly modified and reduced the water exchange with the sea within the central part of the lagoon (Sfriso et al. 1992b). It is therefore not unrealistic to expect that the overall sediment conditions at $\mathrm{Stn} \mathrm{C}$ are well conditioned for anaerobic processes like denitrification of water column nitrate as a response to high organic loading. In contrast to the present study, high denitrification potential at Stn C was found by Silvestri et al. (1995), who estimated the potential denitrification activity in sediments similar to the ones at Stns C and D. BY employing the acetylene inhibition technique at $200 \mu \mathrm{M}$ of nitrate in the water column, they calculated annual ranges for denitrification between ca 200 and $1200 \mu \mathrm{mol} \mathrm{m}^{-2} \mathrm{~h}^{-1}$ in a corresponding Ulva sp. sediment (Stn C) and between 40 and $650 \mu \mathrm{mol}$ $\mathrm{m}^{-2} \mathrm{~h}^{-1}$ in a corresponding Zostera sp. sediment. If linear correlation is assumed between nitrate concentration in the water column (up to $200 \mu \mathrm{M}$ ) and deni- trification, the recalculated denitrification activities from the present'study will be in the same range as the potential activities achieved by Silvestri et al. (1995), $180 \mu \mathrm{mol} \mathrm{m}^{-2} \mathrm{~h}^{-1}$ in the sediment at Stn $\mathrm{C}$ and $330 \mu \mathrm{mol} \mathrm{m}^{-2} \mathrm{~h}^{-1}$ at Stn $\mathrm{D}$. The higher activity estimated by Silvestri et al. (1995) in the Stn C sediment compared to the Stn D sediment to a higher degree than the present study supports the suggested enhancement of denitrification due to high organic load.

Denitrification is to a large extent a function of the capacity of nitrate to diffuse to anaerobic sites as structured by the sediment oxygen penetration depth and the water column nitrate concentration (Christensen et al. 1990, Rysgaard et al. 1994). Therefore, activities measured at nitrate concentrations of $200 \mu \mathrm{M}$ (Silvestri et al. 1995) cannot be considered representative of a field situation at Stns C and D, where the annual range of nitrate in the water is much lower, between $0.7-46$ and $0.7-34 \mu \mathrm{M}$, respectively (CVN 1994). The rates of denitrification observed at Stns C and $\mathrm{D}$ are comparable to the rates measured with the nitrogen-isotope pairing method, in the small shallow estuary of Norsminde Fjord, Denmark (Nielsen et al. 1995). In the Danish estuary, average denitrification ranged between 4.2 and $67 \mu \mathrm{mol} \mathrm{m} \mathrm{m}^{-2} \mathrm{~h}^{-1}$, with a maximum in April when the highest concentration of nitrate was also found in the water column. The sediment in that study varied from being soft mud with an organic content of 10 to $15 \%$ (loss on ignition) to fine/medium sand with organic content of $1 \%$. Overall, both sediment compositions and reported denitrification achieved in the present study are, although in the same magnitude, higher than the ones reported by Nielsen et al. (1995). Presumably, the higher average temperature in the water of the Lagoon of Venice provides for higher decomposition rates and higher overall bacterial activity compared to the Danish estuary, which is why close comparison is hazardous. It should also be mentioned that the laboratory incubation temperature $\left(18\right.$ to $\left.19^{\circ} \mathrm{C}\right)$ was somewhat higher compared to what was measured in the field water at the time of sampling (ca $15^{\circ} \mathrm{C}$ ), which may have resulted in an overestimation of the true field activity under April conditions.

The sediments of Stns A and B both had a pronounced uptake of nitrate which correlated to the registered capacities of denitrification in these areas. However, at all stations there was a high portion of the nitrate uptake that was not explained by the denitrification and we are uncertain if this is due to other bacterial processes within the sediment such as dissimilative nitrate reduction to ammonium, bacterial growth or an underestimation by the method of nitrogen-isotope pairing. 
The sediment efflux of ammonium was observed to be pronounced from all areas except from the sediment at Stns $B$ and $D$. The ammonium release from the sediment at Stns A and C correlates to the high sediment organic content in these areas (Table. 1), which is why this release is likely a result of higher rates of decomposition and mineralization of the particulate organic matter accumulated in these regions. However, this does not clearly correlate with the much higher oxygen consumption rates at Stn A compared with Stn C.

\section{Sediment bioturbation}

As reported by Kristensen (1984, 1985), polychaetes, by their burrowing activity or continuous waterpumping activity, increase the efflux of ammonium to the overlying water. In the present study, ammonium efflux, nitrate consumption and denitrification in the sediment at Stn B correlated to the ambient benthic biomass (Fig. 6). In estuarine coastal areas, bottomdwelling animals have been shown to enhance denitrification by a factor of 2 to 3 , depending on sediment structure and the abundance and type of benthic fauna (Henriksen et al. 1980, Kristensen et al. 1991, Pelegrí et al. 1994). In particular, tube-dwelling animals like Nereis virens and Corophium volutator, which continuously irrigate their burrows, have a large effect on denitrification. Our results clearly corroborated these findings (Fig. 6). The only sediment investigated in the lagoon with significant biomass of infaunal benthos was at $S \operatorname{tn} B$, where an average of ca $5 \mathrm{~g}$ dry weight $\mathrm{m}^{-2}$ was recorded. The correlation found in this study between the total biomass on the one hand, and nitrate and ammonium consumption and denitrification on the other, suggests that the ambient benthic fauna plays a highly significant role for the overall nitrogen turnover in this area. Referring to the regression slopes in Fig. 6 it can be calculated that $5 \mathrm{~g}$ dry weight of infaunal benthos $\mathrm{m}^{-2}$ (tube-dwellers) are responsible for $85 \%$ of the sediment ammonium release at Stn B, 32\% of the nitrate consumption and $30 \%$ of denitrification of water nitrate $\left(d^{14} \mathrm{w}\right)$. Despite that the tidal flats like the one at Stn B only represent around 10 to $20 \%$ of the total Lagoon of Venice sediment area, they are clearly very important for the overall nitrogen removal in the lagoon.

In the sediment at Stn A only one of the investigated cores contained high biomass (i.e. $10 \mathrm{~g}$ dry weight $\mathrm{m}^{-2}$ ) whereas the rest only hosted minor or no biomass. The absence of benthic infauna in the sediments at Stns C and $D$ excludes bioturbation in these areas from being an important contributor to sediment nitrogen cycling, at least during the period in late April when this study was conducted.

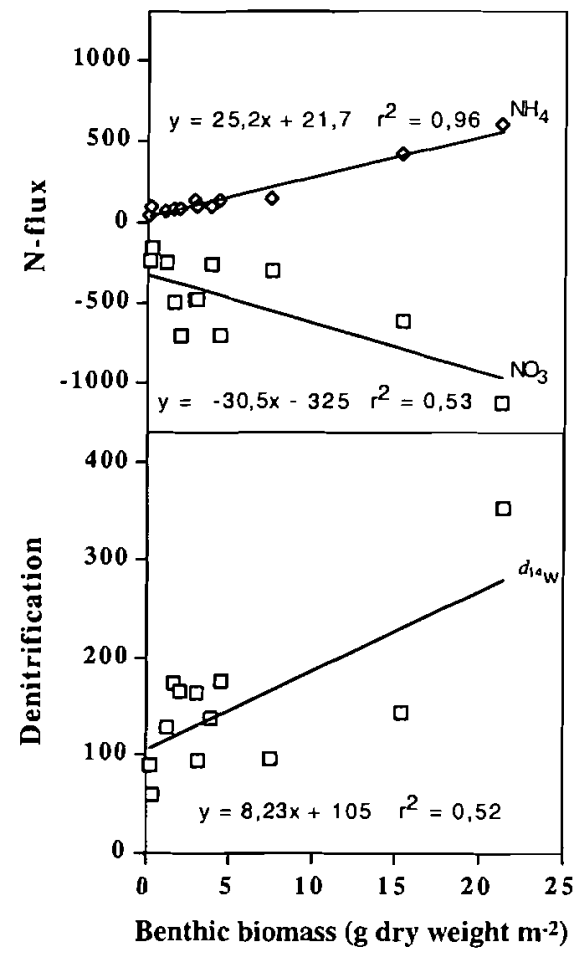

Fig. 6. Fluxes of ammonium and nitrate $\left(\mu \mathrm{mol} \mathrm{m} \mathrm{m}^{-2} \mathrm{~h}^{-1}\right)$ over the sediment surface and denitrification $\left(d^{14}{ }_{w ;} \mu \mathrm{mol} \mathrm{m}^{-2} \mathrm{~h}^{-1}\right)$ of water column nitrate at $S \operatorname{tn} B$ in relation to the ambient biomass (by dry weight) of polychaetes and Corophium sp. found within the sediment. Positive flux values represent fluxes directed from the sediment to the water column and negative fluxes are directed from the water to the sediment

\section{Conclusions}

This study has shown that denitrification in the Lagoon of Venice varies considerably among different sites and that nitrate availability is the main factor regulating the activity in most of the areas as found in many other studies. Another important factor, seldom investigated in undisturbed sediment cores, was bioturbation by tube-dwelling infauna. Bioturbation was found to significantly enhance not only denitrification but also the overall nitrogen cycling in the sediment of the tidal flat (Stn B). Due to the spatial approach of this study representing April conditions only, no attempt was made to estimate the attenuation of nitrogen on an annual basis in the Lagoon of Venice.

Acknowledgements. For valuable comments on earlier versions of the manuscript we thank Prof. G. Bendoricchio and Prof. L. Leonardson. For valuable informative input of the Lagoon of Venice ecosystem, technical help and advice in the laboratory we thank Dario Smania and Dr G. Coffaro. Financial support was generously provided by EU TMR network, grant no. ERBFMRX-CT960051. 


\section{LITERATURE CITED}

Albani A, Favero VM, Barbero RS (1991) The distribution and ecological significance of recent foraminifera in the lagoon south of Venice (Italy). Rev Esp Micropaleontol XXIII: $29-45$

Bendoricchio $G$, Di Luzio $M$, Baschieri P, Capodaglio AG (1993) Diffuse pollution in the Lagoon of Venice. Wat Sci Technol 28:69-78

Bendoricchio G, Coffaro G, De Marchi C (1994) A trophic model for Ulva rigida in the Lagoon of Venice. Ecol Model 75/76:485-496

Bendoricchio G, Zingales F, Carrer GM (1995) Verifica sperimentale di un modello simulazione dei carichi di nutrienti alla scala di bacino. Ing Amb XXIV:277-284

Billen G, Somville M, De Becker E, Servais P (1985) A nitrogen budget of the Scheldt hydrographical basin. Neth J Sea Res 19:223-230

Bocci M; Coffaro G, Bendoricchio G (1997) Modelling of biomass and nutrient dynamics in eelgrass (Zostera marina L): applications to the lagoon of Venice and Øresund (Denmark). Ecol Model 102:67-80

Caffrey JM, Kemp WM (1990) Nitrogen cycling in the sediments with estuarine populations of Potamogeton perfoliatus and Zostera marina. Mar Ecol Prog Ser 66:147-160

Calvo C, Donazollo R, Guidi F, Orio AA (1991) Heavy metal pollution studies by resuspension experiments in Venice Lagoon. Water Res 25:1295-1302

Chaney A, Marbach EP (1962) Modified reagents for determination of urea and ammonia. Clin Chem 8:130-132

Christensen PB, Sørensen J (1986) Temporal variation of denitrificatin activity in plant covered, littoral sediment (Lake Hampen, Denmark). Appl Environ Microbiol 51: $1174-1179$

Christensen PB, Nielsen LP, Sørensen J, Revsbech NP (1990) Denitrification in nitrate-rich streams: diurnal and seasonal variation related to benthic oxygen metabolism. Limnol Oceanogr 35:640-651

Coffaro G, Bocci M (1997) Resources competition between Ulva rigida and Zostera marina: a quantitative approach applied to the Lagoon of Venice. Ecol Model 102:81-95

Cook JG, White RE (1987) Spatial distribution of denitrification activity in a stream draining an agricultural cathment. Freshw Biol 18:509-519

Cossu R, Degobbis D, Donazollo R, Maslowska E, Orio AA, Pavoni $B$ (1983) Nutrient release from the sediments of the Venice Lagoon. Ing San 31:16-23

CVN (Consorzio Venezia Nuova) (1994) Indagini di supporto agli intervent di arresto del degrado. Sintesi dello studio e dei risultati. ENEA-FISIA. Consorzio Venezia Nuova, Venezia (in Italian)

CVN (1996) Proposta per un metodo di valutazione dell'impatto degli scarichi produttivi sull'ambiente lagunare. A cura del Consorzio Venezia Nuova, Servizio InformativoBozza del dicembre 1996 Consorzio Venezia Nuova, Venezia (in Italian)

CVN (1998) Interventi per l'arresto del degrado connesso alla proliferazione delle macroalghe in Laguna de Venezia 1995-1996, Rapporto finale. Consorzio Venezia Nuova, Venezia (in Italian)

Fleischer S, Stibe L, Leonardson L (1991) Restoration of wetlands as a means of reducing nitrogen transport to coastal waters. Ambio 20:271-272

Flindt MR, Kamp-Nielsen L, Marques JC, Pardal MA, Bocci M, Bendoricchio G, Salomonson J, Nielsen SN, Jørgensen SE (1997) Description of the three shallow estuaries: Mondego River (Portugal), Roskilde Fjord (Den- mark) and the Lagoon of Venice (Italy). Ecol Model 102 $17-31$

Granéli E, Wallström $\mathrm{K}$, Larsson $\mathrm{U}$, Granéli W, Elmgren R (1990) Nutrient limitation of primary production in the Baltic Sea area. Ambio 19:142-151

Hauck RD, Melsted SW, Yankwich PE (1958) Use of N-isotope distribution in nitrogen gas in the study of denitrification. Soil Sci 86:287-291

Henriksen K, Hansen JI, Blackburn TH (1980) The influence of benthic infauna on exchange rates of inorganic nitrogen between sediment and water. Ophelia (Suppl) 1:249-256

Izzo G, Creo C, Signorini A, Silvestri C, Spinetti G (1995) Studio ecologico della Laguna di Venezia. Soc Ital Ecol Atti 16:103-106 (in Italian)

Kristensen $E$ (1984) Effect of natural concentrations on nutrient exchange between a polychaete burrow in estuarine sediment and the overlaying water. J Exp Mar Biol Ecol $75: 171-190$

Kristensen E (1985) Oxygen and inorganic nitrogen exchange in a Nereis virens (Polychaeta) bioturbated sedimentwater system. J Coast Res 1:109-116

Kristensen E, Jensen MH, Aller RC (1991) Direct measurement of dissolved inorganic nitrogen exchange and denitrification in individual polychaete (Nereis virens) burrows. J Mar Res 49:355-377

Leonardson L (1994) Wetlands as nitrogen sinks: Swedish and international experience. Swedish Environmental Protection Agency Report No. 4176. Gotab, Stockholm (in Swedish with English summary)

Nielsen K, Nielsen LP, Rasmussen P (1995) Estuarine nitrogen retention independently estimated by the denitrification rate and mass balance methods: a study of Norsminde Fjord, Denmark. Mar Ecol Prog Ser 119:275-283

Nielsen LP (1992) Denitrification in sediment determined from nitrogen isotope pairing. FEMS Microbiol Ecol 86: 357-362

Pelegrí SP, Nielsen LP, Blackburn TH (1994) Denitrification in estuarine sediment stimulated by the ir rigation activity of the amphipod Corophium volutator. Mar Ecol Prog Ser 105:285-290

Pind A, Risgaard-Petersen N, Revsbech NP (1998) Denitrification and microphytobenthic $\mathrm{NO}_{3}$ consumption in a Danish lowland stream: diurnal and seasonal variation. Aquat Microb Ecol 12:275-284

Risgaard-Petersen N, Rysgaard S, Revsbech NP (1993) A sensitive assay for determination of the ${ }^{14} \mathrm{~N} /{ }^{15} \mathrm{~N}$ isotope distribution in nitrate. J Microbiol Methods 17:155-164

Rysgaard S, Risgaard-Petersen N, Sloth NP, Jensen K, Nielsen LP (1994) Oxygen regulation of nitrification and denitrification in sediments. Limnol Oceanogr 39: $1643-1652$

Rysgaard S, Christensen PB, Nielsen LP (1995) Seasonal variation in nitrification and denitrification in estuarine sediment colonized by benthic microalgae and bioturbating infauna. Mar Ecol Prog Ser 126:111-121

Seitzinger SP (1988) Denitrification in freshwater and coastal marine ecosystems: ecological and geochemical significance. Limnol Oceanogr 33:702-724

Sfriso A (1995) Temporal and spatial responses of growth of Ulva rigida $\mathrm{C}$. Ag. to environmental and tissue concentrations of nutrients in the Lagoon of Venice. Bot Mar 38: $557-573$

Sfriso A, Marcomini A (1994) Gross primary production and nutrient behaviour in a shallow coastal environment. Bioresour Technol 47:59-66

Sfriso A, Marcomini A (1999) Macrophytes production in a shallow coastal lagoon. Part II: Coupling with sediment, 
SPM and tissue carbon, nitrogen and phosphorus concentration. Mar Environ Res 47:285-309

Sfriso A, Pavoni B, Marcomini A, Orio AA (1988) Annual variation of nutrients in the Lagoon of Venice. Mar Pollut Bull 19:54-60

Sfriso A, Pavoni B, Marcomini A, Orio AA (1992a) Macroalgae, nutrient cycles, and pollutants in the Lagoon of Venice. Estuaries 15:517-528

Sfriso A, Pavoni B, Marcomini A, Raccanelli S, Orio AA (1992b) Particulate matter deposition and nutrient fluxes

Editorial responsibility: Otto Kinne (Editor),

Oldendorf/Luhe, Germany onto the sediments of the Venice Lagoon. Environ Technol 13:473-483

Silvestri C, Creo C, Russo P, Signorini A, Izzo G (1995) Estimates of denitrification and nitrogen fixation in Venice Lagoon water and sediment. Soc Ital Ecol Atti 16:135-138 Wood ED, Armstrong FAJ, Richards FA (1967) Determination of nitrate in sea water by cadmium-copper reduction to nitrite. J Mar Biol Assoc UK 47:23-31

Zar JH (1974) Biostatistical analysis. Prentice-Hall, Inc, Englewood Cliffs, NJ

Submitted: August 11, 1999; Accepted: January 7, 2000 Proofs received from author(s): May 26, 2000 